\title{
Role of the Traditional Masonry \\ Corporation in the Process \\ of Reconstruction of the Destroyed \\ Mausolees in Timbuktu, Mali
}

\author{
Lassana Cissé
}

\begin{abstract}
The military coup of March 22, 2012, and the yearlong occupation of the northern regions of Mali were followed by the destruction of cultural heritage properties, among them several mausoleums in Timbuktu. As a result, rebuilding damaged cultural heritage properties was one of the many challenges Mali had to face after the liberation of the occupied zones.

Rehabilitation of these properties, particularly the four World Heritage Sites of Mali (Old City of Djenné, Timbuktu, Bandiagara Cliffs, Tomb of Askia), was given government priority. Timbuktu and the Tomb of Askia in Gao had been severely damaged by the armed conflict, and the two sites were placed on the List of World Heritage in Danger in July 2012 at the 36th Session of the World Heritage Committee held in Saint Petersburg, Russia.

Most of the mausoleums, which represent important components of the cultural heritage of Timbuktu, were destroyed. As local cultural practices and rituals were prohibited during the occupation, collective maintenance work of monuments and related buildings by community members could not be done. Ancient manuscripts were burned or taken away, but fortunately most of them were secured and sent to the capital city Bamako until the situation improves in Timbuktu.

Under these circumstances, the Malian Government submitted a request to UNESCO who, in turn, called for the assistance of the international community. Several initiatives were taken, including A Day of Support for Mali's heritage,
\end{abstract}

Published jointly by the United Nations Educational, Scientific and Cultural Organization (UNESCO), 7, place de Fontenoy, 75007 Paris, France, the UNESCO Office in Kabul, ICON Compound, Supreme Road, Off Jalalabad Road, PD 9, Kabul, Afghanistan, and Springer Nature Switzerland AG, Gewerbestrasse 1, 6330 Cham, Switzerland.

L. Cissé $(\bowtie)$

Cultural Heritage, Mali/Heritage and Local Development, Bamako, Mali

(C) UNESCO 2020

M. Nagaoka (ed.), The Future of the Bamiyan Buddha Statues,

https://doi.org/10.1007/978-3-030-51316-0_8 
launched in February 18, 2013 in Paris, which brought together international experts. The meeting led to the approval of "Action Plan for the Rehabilitation of Cultural Heritage and Safeguarding of Ancient Manuscripts in Mali." Funding and technical assistance for the implementation of the Action Plan were provided by Swiss Cooperation, France, Germany, EU, MINUSMA, Bahrain, Croatia, Andorra, AWHF, ICOMOS, ICOM, ICCROM, CRAterre, USAID, Ford Foundation, Hill Museum (USA), Mauritius and the Republic of South Africa.

Implementation of the first phase of the Action Plan required that the local communities be involved in the process, particularly the masons traditionally organized under the professional corporation of masons, the guild of masons. They built the monumental and architectural heritage of the city, and they ensure the maintenance of the monumental buildings, made of local materials, within the city.

The reconstruction strategy of the destroyed mausoleums was designed to favor a participatory approach in order to empower traditional masons and the local workforce from the beginning to the end of the entire process, from March 2013 to September 2015. They worked closely with the national and international architects in charge of the technical supervision of the work. Professional exchanges that took place during the reconstruction of mausoleums allowed visiting architects to better perceive local construction practices and to become familiar with the technical mastery and know-how of the local masons.

Both the technical knowledge and the ritual practices related to traditional masonry were highlighted during the process of reconstruction.

Keywords Heritage $\cdot$ Timbuktu $\cdot$ Mali $\cdot$ Mausoleum · Rebuilding $\cdot$ Recovery · Traditional mason

\section{Introduction}

In April 2012, the Tuareg separatists groups of the National Movement for the Liberation of Azawad (MNLA) and their Islamic allies (AQMI ${ }^{1}$, Ançardine, and $\mathrm{MUJAO}^{2}$ ) seized the northern regions of Mali and established an Islam obedient to Wahhabism characterized by the rejection of the tolerant Islam practiced everywhere in the northern Mali and more particularly in Timbuktu. Salafist barbarism took a heavy toll on the Islamic cultural heritage of Timbuktu, which includes mosques, mausoleums, and ancient Sufi manuscripts. The mosques were vandalized, the mausoleums and the El Farouk Monument bulldozed, and old manuscripts burned or taken away.

\footnotetext{
${ }^{1}$ Al Qaïda Islamic Maghreb.

${ }^{2}$ Movement for Unity and Jihad in West Africa.
} 
At the liberation of these regions in March 2013, a vast reconstruction movement was undertaken by the Malian authorities and the international community led by UNESCO. In the reconstruction program, the rehabilitation of the heritage was especially important because of the damage caused during the occupation which lasted a year.

One of the principles adopted by UNESCO and the Malian Ministry of Culture was to undertake a reconstruction of the mausoleums in traditional ways, respecting the original specificities of the different sites. It also aimed at observing international conservation standards and principles, in line with the Operational Guidelines for the Implementation of the 1972 Convention Concerning the Protection of the World Cultural and Natural Heritage.

The sites of Timbuktu are architectural and earthen buildings that embody the ancestral know-how of the traditional masons. This know-how thus provided for the maintenance of the mausoleums and mosques and embellished the landscape of the medina mainly built in earth and alhor stone.

However, long before the Islamist occupation, the earthen architecture had been marred by the use of cement, concrete, and scrap metal, as well as by wall inscriptions and other advertising signs that reflected the mass culture, globalization, and new economic values induced by the consumer society. The traditional masons sometimes used cement because of economic constraints.

When the reconstruction of the mausoleums and other World Heritage properties began, the role of the traditional mason was reinstated. This was an opportunity to revitalize and revalorize traditional knowledge and practice to the benefit of the conservation process and the sustainable management of cultural heritage resources in general and those of World Heritage in particular.

The expertise of the traditional masons includes the mastery of the techniques of construction in both earth and alhor ${ }^{3}$ stone and the development of plans. The traditional mason must know the proper methods for cutting alhor stone as a building material and how to find proper sort of earth for the type of building to be restored. The mason must also know how to select and install beams of rôniers ${ }^{4}$ and the plant mats for roofs.

More than a simple builder, the traditional mason is a man rooted in his social milieu and his belief systems. These are often metaphysical, based mainly on ancestral ritual practices. The mason is considered to be endowed with supernatural powers that allow him to heal diseases, ward off bad luck, and destroy invisible enemies. All these ancient practices were banned by the Islamist occupation that considers them contrary to orthodox Wahhabi, even satanic.As we can see, the traditional mason's know-how is also a way of life which, even if it is material, is based on an intangible foundation.

\footnotetext{
${ }^{3}$ Limestone used for local building material at Timbuktu.

${ }^{4}$ Local palm tree used as wood for constructions.
} 
This study therefore aims to identify the knowledge and skills inherent in the traditional masonry method and to show how it is or should be used in the reconstruction, restoration, and maintenance process of heritage buildings, with a view to sustainable conservation essentially ensured by the local communities holding these values.

\section{Brief Overview of Timbuktu's History and Traditional Masonry Corporations}

Timbuktu is a city steeped in history and mystery. By traditional account, the creation of Timbuktu dates back to the twelfth century. Originally, it was only a small transit center created around a well, hence its name Tim Bouctou which literally means in Kel Tamasheq "the well of Bouctou," an old woman Tamasheq to which is attributed the construction of the well. This small camp welcomed the caravans (Azalai) after the long crossing of the desert underwent a spectacular development because of its strategic position in contact with the Sahara and the Niger River.

A reliable relay point between the Maghreb and Sudan, many desired the control of Timbuktu. It was annexed by the Mansa (Kings) of the Empire of Mali who played an important role in furthering its cultural influence. Following his pilgrimage to Mecca in 1324-1325, Kankou Moussa (one of the greatest emperors of Mali) built the first mosque, that of Djingareyber. In the fifteenth century, the city was annexed by the Songhay Empire and became one of the most important centers of Islamic culture with many universities including the famous mosque - University of Sankore which welcomed more than 25,000 students from both Sudan (Jenne, Agadès, Walata) only from the Mediterranean world (Fez, Marrakech, Cairo).

After the Moroccan invasion in 1591, Timbuktu became the capital of the Arma state of Pacha Djouder, created by descendants of the Moroccan conquerors.

Timbuktu is a city located between the Sahara Desert and the Niger River; a geographical location that makes it the meeting point and refuge of sedentary traders or craftsmen and nomadic transhumant pastoralists. The landscape was sparsely covered by huts and other round structures that provided protection from the dust and the burning sun of the desert.

The small hamlet of huts that was established here was a place of passage for rich traders and artisans from the south, including those from Jenne, who traded with the Maghreb. These rich merchants, only passing through, wanted to build comfortable places to live while they were there and brought masons from Jenne where the earthen architecture was already established. They constructed in the present district of Badjindé the first buildings in earth. The mud house became associated with wealth, a sign of belonging to the local aristocracy made up of the Maiga and Wangara families who still populate this district that is the epicenter of Timbuktu. 
Although a Muslim city, animism was the traditional religion and was practiced there particularly by craftsmen and those coming from localities bordering the Niger River. In this system of belief, any form of manual labor and especially the work of the earth is regarded as sacred and remains linked to immaterial metaphysical practices. Those who work the earth are supposed to have supernatural powers as evidenced by their skill that gives them the ability to rise higher than everyone to build a wall, or sink into the bowels of the earth to make the foundations. The mason is therefore considered a supernatural man who builds the houses but also ward off bad luck, someone able to come into contact with beneficent spirits to drive out the evil ones.

Under the influence of masons from Jenne, the architecture of the small hamlet changed gradually but significantly. The social structure changed also with the emergence of a new class of craftsmen who impelled the local economy. The fame of the city grew. It attracted those voracious for wealth. Emperor Kankou Moussa ${ }^{5}$ on his pilgrimage to Mecca seized the city and on his return built the famous Djingareyber Mosque in 1325. He did this with the help of an Andalusian architect Abu Ishaq Es-Saheli or Es Seqli, who reorganized the corporation of masons and introduced them to new architectural techniques including arcades, warheads, hinges, and wall inscriptions; houses that had previously been on one level now had at least one floor.

The search for sources of better clay led to the discovery of the alhor stone, a porous and corrosive material but which will be used to consolidate the walls. A masonry guild led by the Koba Hou family established around the mosque and still provides daily maintenance and annual renovation.

A few decades later, a woman from Walata - now in Mauritania - sponsored the construction of Sankore Mosque by the local masonry corporation. The Sankore Mosque eventually came under the control of the Askia dynasty. It had become a university that was the center of most of the intellectual and cultural power of the city. Several disciplines were taught there, and the opinions of the scholars at the university had the force of law. To advance the development of earthen architecture, the masons, involved in the construction and maintenance of this mosque from the Hamane Hou family, kept some leadership on all matters related to earthen architecture.

Thus two powerful mason corporations were born with Koba Hou in Djingareyber and Hamane Hou in Sankore. The two wings of the guilds are autonomous, but Hamane Hou alone has the power and the authority to speak on behalf of all the masons. The corporation is governed by guiding principles and a code of ethics passed down by oral tradition that are rigorously respected.

\footnotetext{
${ }^{5}$ Mandingo king, one of successors of Sunjata Kéita, founder of the Mali Empire in thirteenth century.
} 


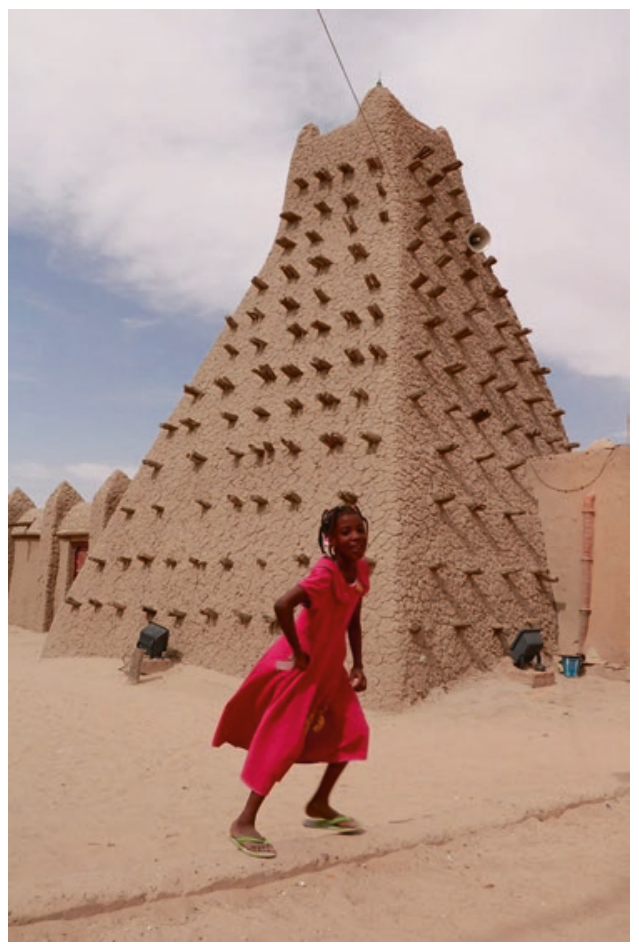

\section{The Origin of the Traditional Masonry or How to Become Mason}

Today the masons' corporation is open to all those who are interested in the profession but formerly, and as for all traditional vocations, knowledge and practices were transmitted exclusively from father to son. Still today, however, any young person from a family of masons should learn the profession at an early age. The classic curriculum is that every morning the young person of 10-12 years should prepare the tools of his master - who is not necessarily his father - and go to the site to observe, make commissions, and transport the banco (the mixture of clay and rice straw traditionally used in making bricks and on the façade of houses), bricks and alhor stone.

At the age of 15 , he is allowed to ride a donkey outside the city to find good quarries of alhor and land, to enter the quarries and extract the best stone, and then to transport it back by camel. He is then introduced to the work of kneading clay into banco and carving alhor stone. This is done without being remunerated; his pay 
always goes to his master who, on holidays, can make him a boubou (a garment) or pay his medical expenses in case of illness.

After completing his Koranic studies, usually between the ages of 20 and 25, he is introduced to the secret sciences of the corporation, sciences that consist essentially of esoteric words that when uttered ensure safety on the building sites, ward off bad luck, eliminate possible enemies, and heal wounds and scorpion and snake bites. He is then entitled to "climb on a wall and climb a wall."

\section{The Basic Elements of the Process of Employing Traditional Masons in the Reconstruction of Timbuktu's Mausoleums}

The involvement of the Timbuktu traditional masonry guilds in the process of rebuilding the mausoleums was a challenge in light of the World Heritage status of the propertied, which include the famous 3 mosques and the 16 mausoleums registered since 1988 .

The first basic principle was that the involvement and empowerment of the masons in the process was essential because these masons belonged to families and guilds that developed a culture that dates back to the original structures in Timbuktu and other localities of the Niger River Valley. These masons, whose ancestral knowledge and know-how is transmitted from generation to generation, were to be the core of construction efforts for all the mausoleums destroyed in 2012 in Timbuktu.

Secondly, the strong participation of masons presented an incredible opportunity to boost and promote the local economy hard hit by both the crisis of lost tourism and the insecurity resulting from the armed conflict.

The last principle supporting the use of traditional masons in the project was the desire to perpetuate ancestral building practices that had been subject to the effects of what were feared to be irreversible mutations due to several endogenous and exogenous factors.

\section{Role of the Traditional Masons' Guilds in the Process of Reconstruction of the Destructed Mausolees in Timbuktu}

The reconstruction of the mausoleums was an opportunity to update the traditional masonry know-how and practices. From the beginning of the project, it was decided to do everything possible to maintain these traditional practices. 
First, the expertise and leadership of the masons' guilds were respected. The two corporate heads were immediately made supervisors of all the work. Each mausoleum manager designated his family mason for the reconstruction work. They recruited the workers of their choice and, with the architects, ordered the necessary materials for the work. A beverage consisting of a cream of millet was served on all sites. Local materials, earth, alhor stone, and earth from the land of Bourem with traditional ingredients and adjuvants including baobab powder, shea butter, and rock salt, are exclusively used in the construction...

Rituals for launching and closing work were also planned. Two important events attended the process of reconstruction of mausoleums in Timbuktu. These were the prayer ceremony followed by the burial of the seven cereals in the foundation of the first two mausoleums (Baba Idje and Al Fulani) adjoining the mosque of Djingareyber and the sacralization ceremony held inside the same mosque.

The traditional masonry method is based on intangible culture, practices that provide the foundation for the techniques and methods of construction in Timbuktu. The immaterial is also essential to the creation of the masons' corporations as well in Jenne as in Timbuktu. Initiation ceremonies, rites of passage, and beliefs related to the supernatural are managed within a social class (sometimes endogamous) that retains a monopoly on the art of building and preserving habitat and other forms of life buildings built within the city.

In the ancestral belief of Timbuktu, the mausoleums and tombs of scholars who have figured greatly in the history of the city form a protective whole for the city and protect it from all misfortune. The 14 main saints (one of whom, Sidi Yahia, has the special status of main saint of the city) represent the cultural diversity of Timbuktu and thus testify to the openness of this city to those from abroad and its ability to establish favorable conditions for the "living together" of several complementary communities.

Moving forward, the safeguarding plan must necessarily rely on intangible heritage elements as part of a very long-term strategy for the restoration of mausoleums and other buildings in the region. This is important because the work of restoration has always been organized on the basis of cultural references drawn from intangible cultural expressions. It is therefore a question of better structuring certain cultural events and the traditional cultural context in which construction is done. This cultural endogeny will promote the sustainable protection and management of ancient sites and monuments in Timbuktu and other cities. 


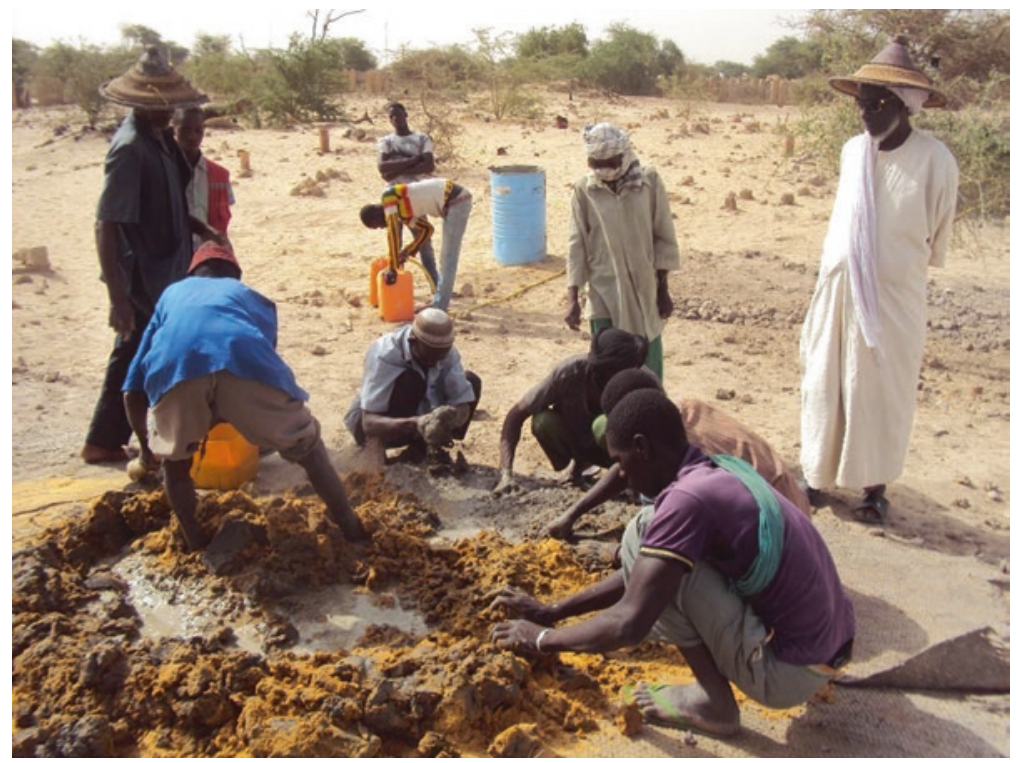

\section{The Ritual and Intangible Manifestations of Traditional Masonry}

In Timbuktu, each socio-professional community has a dance of its own. For the masons, it is the Dimba, which is exclusively reserved for their guild. It is done in all the celebratory social events directly involving a mason (festive gatherings of masons, during collective work on the mosques of Sankore or Djingareyber, marriages, circumcisions). It can also be done for the reception of a distinguished guest such as one holding a notable administrative or political position. The Dimba was born in the mosque of Djingareyber, and it is often the guild of this district that summons the dancers. Cola nuts are sent to convene the dancers.

This festive ceremony is usually held during the official opening of the building, once the construction work has been completed. On occasion, the keys of the house are officially and symbolically handed to the owner.

\section{Stages of Intangible Practices in the Construction Process at Timbuktu}

Traditional masonry as practiced by the masons of Timbuktu is a process that takes several steps, from the foundation of a house through the roof to the finishing works which consist of the coatings and the fixing of the furniture on the openings. These 
stages are marked by ceremonies and significant ritual practices, some of which are esoteric and others that are more secular such as dances and ceremonies of sacralization.

In general, daily prayers punctuate the stages of masonry. They are based on the wishes of the mason and the objectives he sets to carry out the work without major incident.

(a) The ritual ceremony of seven cereals for the realization of the foundations of the walls

In the ritual practices of masonry in Timbuktu, at the start of any significant construction site, the masons bury grain products. The number of these products must be odd. Among the most popular cereals are sorghum, rice, wheat, beans, cotton, millet, and maize.

According to the traditions collected from some old masons in Timbuktu, the number seven is most often mentioned. But in reality, it varies according to the abundance or shortage of certain cereals (periods of good or bad harvests). The figure can greatly exceed seven but remains odd. This is to signify the unshakeable links between the economic power of agricultural production and the resources necessary to the construction process. This can also determine the dimensions of the building to be built. A monumental building can receive more than seven agricultural products, while a small building can receive less (five or three).

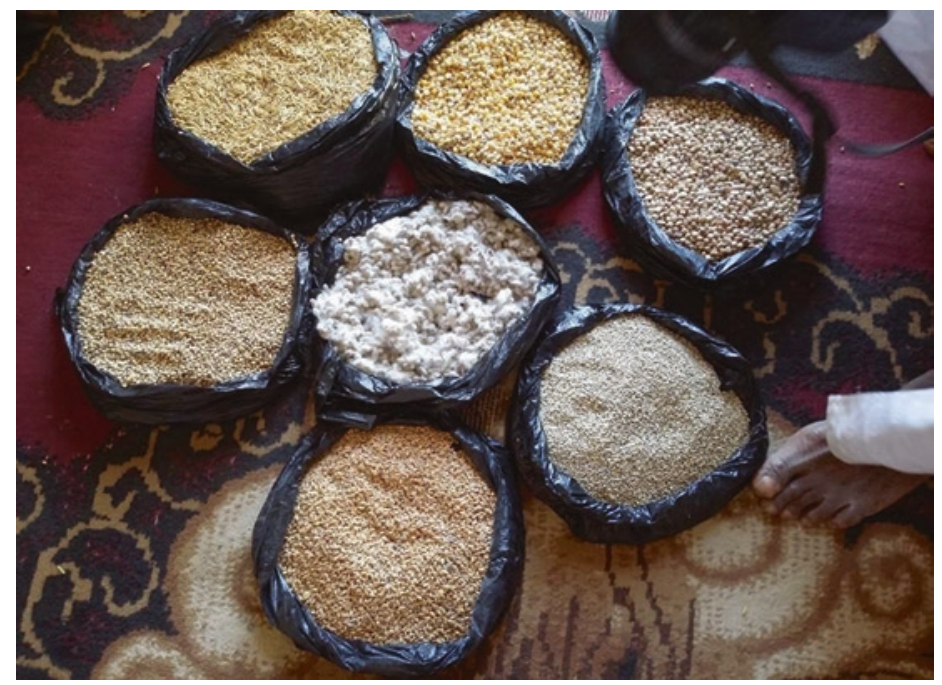

(b)Ceremonies of sacralization for some buildings to mark the end of the construction site

In Timbuktu, the end of great masonry projects is marked by a ceremony of sacralization that is summarized by a collective prayer of the Holy Quran. The ceremony usually takes place on site and includes several religious leaders and members of the masons' guilds. It is often an opportunity for a feast organized by the 
owner or managers of the building when it is public (mosque, mausoleum or house of lineage, etc.). Prayers are said by scholars of the city who master the surates of the Quran.

Some ceremonies marking the end of construction work may be a family celebration or a festive meeting when the mason with authority over the work at the site is satisfied with the quality of the work done or when the site has provided him with substantial income. This is an expression of solidarity and sharing within the guild.

Nevertheless, it should be noted that ceremonies of sacralization are not obligatory; they depend upon the goodwill or initiative of the owner or managers of the buildings constructed.

(c) Other immaterial practices related to traditional masonry: totemic practices related to traditional masonry

In the masons' guilds of Jenne and Timbuktu, and in some other circles of traditional masonry, totemism is quite developed. Ancient beliefs include, for example, that any animal or living being that knows how to climb must be the object of protection on the part of the mason. For example, it is strictly forbidden for a traditional mason to kill a lizard, or a margouillat ${ }^{6}$. These reptiles are considered "masons" because they rarely fall from the heights of a built wall. In this spirit and according to this perception, the lizard and the margouillat are supposed to protect the mason when he is on the scaffold.

A traditional mason must not crush an ant when it is climbing. Traditionally, masons have scrupulous respect for the preservation of certain elements of the natural environment.

\section{Conclusion}

Traditional masons played a leading role in the process of rebuilding and rehabilitating mausoleums in Timbuktu. Their guilds, which date to the original development and dissemination of technical and cultural construction practices throughout the Niger River Valley centuries ago, have been able to ensure strong community participation in the reconstruction of the 16 mausoleums destroyed in 2012.

The efforts of these masons have been recognized both locally and nationally. UNESCO honored them with a medal at the 40th session of the World Heritage Committee held in June 2015 in Bonn, Germany.

Without the participation of the Timbuktu masonry guilds in the reconstruction program of the destroyed mausoleums, the successful restoration of them would be hard to imagine.

The Timbuktu masons, contributing to the reconstruction of the mausoleums, have above all strengthened the professional capacities of young masons while ensuring the transmission of ancestral knowledge and know-how in the field of the sustainable conservation of the thousand-year-old architectural heritage.

${ }^{6}$ Local lizard 


\section{Bibliography}

Celtho, la Charte de Kurukan Fuga. Aux sources d'une pensée politique en Afrique, $2^{\text {ème }}$ édition, Harmattan Burkina Faso, Nov. 2013.

Cissoko, Sékéné-Mody. Tombouctou et l'Empire songhay : épanouissement du Soudan nigérien aux XVe-XVIe siècles. Dakar : Nouvelles éditions africaines, 1975.

Conrad, D. C. (2016). Sunjata a new prose version. by Hackett Publishing Company, Indianapolis/ Cambridge.

Drissa Diakité, Kuyatè la force du serment ; aux origines du griot Mandingue, $3^{\text {ème }}$ édition La Sahélienne, 2017.

Kum'a Ndumbe III, le trésor des manuscrits de Timbuktu. Un appel à la mémoire collective de l'Afrique et du monde, Editions AfricAvenir, Douala, 2017.

L'Histoire n³67, septembre 2011 : «Les siècles d'or de l'Afrique ».

Mauro Bertagnin et Ali Ould Sidi. (2014). Manuel pour la conservation de Tombouctou. In Unesco.

(2017). Patrimoines endommagés des Régions du nord du Mali : sauvegarde, reconstruction, réhabilitation, restauration, revitalisation, (bilan de la phase 1). UNESCO, mars.

Pietro, M. (2014). Apollonj Ghetti. Unesco: Étude sur les mausolées de Tombouctou.

Ministère de la culture. Plan de Gestion et de Conservation 2006-2010.

Priez, Marie-Aude. Tombouctou et les villes du fleuve: Ségou, Djenné, Mopti. Paris : ASA éd., 1999. $88 \mathrm{p}$.

ICCROM. Protection juridique du patrimoine culturel immobilier : Orientations pour les pays francophones de l'Afrique Subsaharienne, ICCROM Studies9, 2004.

DNPC -UNESCO.Rapport final et plan d'action pour la réhabilitation du patrimoine culturel et la sauvegarde de manuscrits anciens du mali, 2013.

Mission Culturelle Tombouctou. Rapport sur l'état de conservation du bien culturel Tombouctou, Ministère de la Culture, 2017.

UNESCO. Politiques pour la créativité., Guide pour le développement des industries culturelles et créatives, 2012.

UNESCO. Patrimoine mondial., Bénéfices au-delà des frontières, 2013.

UNESCO. Engager les communautés locales dans la gérance du patrimoine mondial. Méthodologie fondée sur l'expérience de COMPACT.

The opinions expressed in this chapter are those of the author(s) and do not necessarily reflect the views of the UNESCO, its Board of Directors, or the countries they represent.

Open Access This chapter is licensed under the terms of the Creative Commons AttributionShareAlike 3.0 IGO License (https://creativecommons.org/licenses/by-sa/3.0/igo/), which permits use, sharing, adaptation, distribution, and reproduction in any medium or format, as long as you give appropriate credit to UNESCO, provide a link to the Creative Commons licence and indicate if changes were made. If you remix, transform, or build upon this chapter or a part thereof, you must distribute your contributions under the same licence as the original. This publication is also available at the UNESCO Open Access Repository: https://unesdoc.unesco.org/

The designations employed and the presentation of material throughout this publication do not imply the expression of any opinion whatsoever on the part of UNESCO concerning the legal status of any country, territory, city or area or of its authorities, or the delimitation of its frontiers or boundaries.

The authors are responsible for the choice and the presentation of the facts contained in this chapter and for the opinions expressed therein, which are not necessarily those of UNESCO and do not commit the Organization.

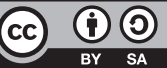

